\title{
DISTRIBUTION OF ACTIVE HEPATITIS C INFECTED POPULATION BY SEX AND AGE GROUPS IN DISTRICT D.I.KHAN, PAKISTAN
}

\author{
Imran Ullah1, iD Nisar Khan², (DZakirullah Khan³, Fahim Ullah Khan', (DAbdurrehman Khan², \\ iD Shafaat Ur Rehman ${ }^{4}$ \\ 'District Health Office, D.I.Khan, ${ }^{2}$ Department of Medicine, MMMT Hospital, D.I.Khan, ${ }^{3}$ District Health Office \& \\ ${ }^{4} \mathrm{DHQ}$ Hospital, Lakki Marwat, Pakistan
}

\begin{abstract}
Background: Untreated hepatitis C virus infection is major cause of cirrhosis and hepatocellular carcinoma causing significant morbidity and mortality. Our objectives were to determine distribution of active hepatitis $\mathrm{C}$ infected population by sex and age groups in District D.I.Khan, Pakistan.

Materials \& Methods: This cross-sectional study was conducted at District Health Office, D.I.Khan, Pakistan from 25 April 2021 to 12 May 2021. Data was collected for period from 11 February 2017 to 22 April 2021. 1062 active hepatitis $\mathrm{C}$ infected cases were selected from population at risk consecutively. Sex (nominal) and age groups (ordinal) were variables. Distribution was analyzed by count, percentage and confidence intervals for proportion for population. Hypotheses for distribution were substantiated by chi-square goodness-of-fit test.

Results: Out of 1062 active hepatitis C infected population, 569 (53.58\%) were men \& $493(46.42 \%)$ women, and $51(4.80 \%)$ in age group 0-20 years, $433(40.77 \%)$ in $21-40,476(44.82 \%)$ in $41-60$ \& $102(9.61 \%)$ in $>60$ years. Our distribution by sex $(p<.00001)$ and age groups $(p<.00001)$ was different than expected.

Conclusion: In our study, active hepatitis $C$ infection was more common in men than women and most common in age group 41-60 years, followed by 21-40, >60 \& 0-20 years. Our observed prevalence of active hepatitis C infection in men was lower than expected \& in women it was higher than expected. Our observed prevalence of active hepatitis $C$ infection in the four age groups was not similar to expected.

KEY WORDS: Hepatitis C; Hepatitis C virus; Distribution; Prevalence; Incidence; Population; Sex; Age groups; Chi-square Goodness of fit Test; Pakistan.

Cite as: Ullah I, Khan N, Khan Z, Khan FU, Khan A, Rehman SU. Distribution of active hepatitis C infected population by sex and age groups in District D.I.Khan, Pakistan. Gomal J Med Sci 2021 Jul-Sep; 19(3):85-90. https://doi.org/10.46903/gjms/19.03.1018
\end{abstract}

\section{INTRODUCTION}

1.1 Background: Globally in 2019 prevalence, incidence and mortality of hepatitis $\mathrm{C}$ virus infection was about $0.8 \%, 1.5$ million and 0.29 million respectively. ${ }^{1}$ Untreated HBV and HCV infections are leading causes of cirrhosis and hepatocellular carcinoma and are responsible for $96 \%$ mortality due to viral hepatitis. In 2015, 2.3 million HIV infected patients also had HCV infection.

\section{Corresponding Author:}

Dr. Imran Ullah

Medical Specialist

District Health Office

D.I.Khan, Pakistan

E-mail: drimranullah89@gmail.com

Date Submitted: 15-05-2021

Date Revised: 20-06-2021

Date Accepted: 25-06-2021
$\mathrm{HCV}$ in the European and Eastern Mediterranean regions is more prevalent. ${ }^{2}$ In 2019, in Eastern Mediterranean Region, the prevalence, incidence and mortality of hepatitis $\mathrm{C}$ infection were $1.6 \%, 0.47$ million and 31,000 respectively. ${ }^{1}$

Suntur, et al. ${ }^{3}$ from Adana, Turkey during Jun. 2016 to Oct. 2018 distributed 869 active HCV infection cases as $69.51 \%(604 * 100 / 869=69.51)$ men and $30.49 \%$ $(265 * 100 / 869=30.49)$ women.

Soliman, et al. ${ }^{4}$ from Luxor, Egypt during June 2016 to May 2017 distributed 9,701 seropositive HCV infections as $35.18 \%\left(3413^{*} 100 / 9701=35.18\right)$ men and $64.82 \%(6288 * 100 / 9701=64.82)$ women.

Sharma, et al. ${ }^{5}$ from India showed in year 2020 the distribution of 102 seropositive HCV infections as $47.06 \%(48 * 100 / 102=47.06)$ men and $52.94 \%(54 * 100 / 102=52.94)$ women. Kumar, et al. ${ }^{6}$ from Peshawar, Pakistan during Feb. 2013 to Jan. 2015 reported 123 active HCV infection cas- 
es, including $43.09 \%(53 * 100 / 123=43.09)$ men \& $56.91 \%(70 * 100 / 123=56.91)$ women, and $8.94 \%$ $(11 * 100 / 123=8.94)$ in age group $10-20$ years, $38.21 \%(47 * 100 / 123=38.21)$ in $21-40 \& 52.85 \%$ $\left(65^{\star} 100 / 123=52.85\right)$ in $\geq 41$ years.

Ahsan, et al. ${ }^{7}$ from Peshawar, Pakistan during Sep. 2016 to Feb. 2017 found distribution of 541 seropositive HCV infection as $48.24 \%(261 * 100 / 541=48.28)$ men \& $51.76 \%(280 * 100 / 541=51.76)$ women, and $7.02 \%(38 * 100 / 541=7.02)$ in age group $0-20$ years, $44.55 \%(241 * 100 / 541=44.55)$ in $21-40$, $42.33 \%(229 * 100 / 541=42.33)$ in $41-60 \& 6.10 \%$ $\left(33^{*} 100 / 541=6.10\right)$ in $\geq 61$ years.

Ullah, et al. ${ }^{8}$ from Mardan, Pakistan for the period 2017-2020 found distribution of 378 active HCV infection as $61.38 \%(232 * 100 / 378=61.38)$ men \& $38.62 \%(146 * 100 / 378=38.62)$ women and $6.88 \%(26 * 100 / 378=6.88)$ in age groups $11-20$ year, $47.09 \%(178 * 100 / 378=47.09)$ in $21-40$, $45.24 \%(171 * 100 / 378=45.24)$ in $41-60 \& 0.79 \%$ $(3 * 100 / 378=0.79)$ in $\geq 61$ years.

Khan, et al. ${ }^{9}$ reported 17 active HCV infections from Takht Bhai, Mardan, Pakistan in 2018, including $76.47 \%\left(13^{*} 100 / 17=76.47\right)$ men and $23.53 \%$ $(4 * 100 / 17=23.53)$ women.

Khan, et al. ${ }^{10}$ reported 23 active HCV infections from Batkhela, Malakand District, Pakistan in 2018, including $56.52 \%\left(13^{*} 100 / 23=56.52\right)$ men \& $43.48 \%$ $(10 * 100 / 23=43.48)$ women. He also reported 41 seropositive HCV infections as $12.19 \%\left(5^{*} 100 / 41=12.19\right)$ in age group 0-20 years, $29.27 \%(12 * 100 / 41=29.27)$ in $21-40,31.71 \%\left(13^{*} 100 / 41=31.71\right)$ in $41-60$ \& $26.83 \%(11 * 100 / 41=26.83)$ in $\geq 61$ years.

Jan, et al. ${ }^{11}$ published 45 seropositive HCV infections from Bannu, Pakistan in 2020, including $64.44 \%$ $(29 * 100 / 45=64.44)$ men \& $35.56 \%(16 * 100 / 45=35.56)$ women, and $6.67 \%(3 * 100 / 45=6.67)$ in age group $01-15$ years, $33.33 \%(15 * 100 / 45=33.33)$ in $16-30,31.11 \%(14 * 100 / 45=31.11)$ in $31-45$, $24.44 \%(11 * 100 / 45=24.45)$ in $46-60 \& 4.44 \%$ $(2 * 100 / 45=0.20)$ in $61-75$ years.

1.2 Research problems (RPs), Knowledge Gaps (KGs), Research Questions (RQs) \& Rationale: Unawareness regarding the distribution of active hepatitis $C$ infected population by sex and age groups in District D.I.Khan, Pakistan were our two RPs. We could not retrieve the relevant data from various databases/ search engines. Lack of these information were our two KGs. What will be the distribution of active hepatitis $C$ infected population by sex and age groups in District D.I.Khan, will be our two RQs? The rationale of our study will be to answer these two $R Q$ s, fill these two KGs and hence solve our two RPs.

\subsection{Research Objectives (ROs)}

RO 1: To find out the distribution of active hepatitis C infected population by sex in District D.I.Khan, Pakistan.
RO 2: To find out the distribution of active hepatitis C infected population by age groups in District D.I.Khan, Pakistan.

\subsection{Research (Null) Hypotheses}

$\mathbf{H}_{01}$ : The observed distribution of active hepatitis $\mathrm{C}$ infected population by sex was matching to its expected distribution in District D.I.Khan, Pakistan.

$\mathbf{H}_{02}$ : The observed distribution of active hepatitis $\mathrm{C}$ infected population by age groups was matching to its expected distribution in District D.I.Khan, Pakistan.

\section{MATERIALS AND METHODS}

2.1 Study Design, Settings \& Duration: This cross-sectional study was executed at the District Health Office, D.I.Khan, Pakistan from 25 April 2021 to 12 May 2021. Hospital Ethical Review Committee assented to the project before its inception.

2.2 Population \& sampling: The population of District D.I.Khan was 1,625,088 in 2017 census. With $1.6 \%{ }^{1}$ expected prevalence rate of $\mathrm{HCV}$ in this population at risk, margin of error $0.7212 \%$ and confidence level of $95 \%$, sample size came to be 1,062 through online calculator, ${ }^{12}$ using consecutive sampling approach. All active hepatitis C infected patients were eligible for inclusion.

2.3 Conduct of procedure: The data was collected from computer records of "Hepatitis Control Program" office of MMMT Hospital, D.I.Khan for the duration of four years from Feb. 11, 2017 to Apr. 21,2021 , after approval from the concerned stake holders. Detailed information was obtained from patients regarding clinical features, risk factors, co-morbidities and previous treatment. Necessary investigations like HCV antibodies detection by ICT and/ or by ELISA and ultrasound abdomen etc. were performed. Active hepatitis $C$ infection was confirmed on polymerase chain reaction (PCR). After confirming diagnosis, patients were started on recommended antiviral treatment.

2.4 Data Collection Plan: Data was retrieved for these two variables (groups); sex (men/ women) and age groups (0-20, 21-40, 41-60 and $>60$ years). The data type was nominal for sex and ordinal for age groups.

\subsection{Data Analysis Plan}

2.5.1 Descriptive Statistics and estimation of parameters: These two variables were analyzed by count and percentage for the sample. The population parameters were deduced from sample statistics as confidence intervals at $95 \% \mathrm{CL}$, using normal approximation method. ${ }^{13}$

2.5.2 Testing of Hypotheses: The two null hypotheses $\left(\mathrm{H}_{0} \& \mathrm{H}_{02}\right)$ were validated by chi-square goodness-of-fit test each. Observed counts $(O)$, expected counts $(E), O-E, O-E^{2}, X^{2}, \Sigma X^{2}$, degree of freedom (d.f.) and $p$-value are given at $\alpha .05 . .^{14-16}$ 


\section{RESULTS}

3.1 Descriptive Statistics \& Estimation of Parameters 3.1.1 Distribution of active hepatitis $C$ infected population by sex and age groups: Table 3.1.1 highlights the distribution of 1,062 active hepatitis $\mathrm{C}$ infected population by sex and age groups. Here active hepatitis $\mathrm{C}$ infection was more common in men $53.58 . \%$, than women $46.42 \%$, and most common in age group $41-60$ years $(44.82 \%)$, followed by $21-40$ years $(40.77 \%),>60$ years $(9.61 \%) \& 0-20$ years (4.80\%).

\subsection{Testing of Hypotheses}

3.2.1 Observed vs. expected distribution of active hepatitis $C$ infected population by $\operatorname{sex}\left(\mathrm{H}_{01}\right)$ : Chisquare goodness-of-fit test testifies the difference between the observed counts from our sample $(n=1062)$ in column 2 (C2) against expected counts (C3) from a study by Ullah, et al. ${ }^{8}$ from Mardan,
Pakistan $(n=378)$. With difference in sample sizes/ denominators, the expected counts are adjusted to our sample size (C4). C5, C6 \& C7 shows relevant percentages. (Table3.2.1.1)

With p-value <.0001, $\mathrm{H}_{01}$ was rejected, confirming that the observed counts are different from the expected counts. Simply, our observed prevalence in men $53.58 \%$ was lower than expected (adjusted) for men $61.38 \%$ \& in women $46.42 \%$ it was higher than expected (adjusted) for women $38.62 \%$. (Table 3.2.1.2)

3.2.2 Observed vs. expected distribution of active hepatitis $\mathbf{C}$ infected population by age groups $\left(\mathrm{H}_{\mathrm{O}_{2}}\right)$ : Chi-square goodness-of-fit test testifies the difference between the observed counts from our sample $(n=1062)$ in column 2 (C2) against expected counts (C3) from a study by Ullah, et al. ${ }^{8}$ from Mardan, Pakistan $(n=378)$. With difference in sample sizes/ denominators, the expected counts

Table 3.1.1: Distribution of active hepatitis $\mathrm{C}$ infected population by sex and age groups in District D.I.Khan, Pakistan

\begin{tabular}{|l|l|c|c|c|c|}
\hline \multirow{2}{*}{ Variables } & \multirow{2}{*}{ Groups } & \multicolumn{2}{|c|}{ Sample analysis } & \multicolumn{2}{c|}{$95 \%$ Cl for proportion } \\
\cline { 2 - 6 } & & Count & Percentage & Lower & Upper \\
\hline \multirow{2}{*}{ Sex } & Men & 569 & $569 * 100 / 1062=53.58 \%$ & 50.57 & 56.56 \\
\cline { 2 - 6 } & Women & 493 & $493^{*} 100 / 1062=46.42 \%$ & 43.44 & 49.43 \\
\hline \multirow{4}{*}{$\begin{array}{l}\text { Age groups } \\
\text { (years) }\end{array}$} & $0-20$ & 51 & $53^{*} 100 / 1062=4.80 \%$ & 3.67 & 6.26 \\
\cline { 2 - 6 } & $21-40$ & 433 & $433^{*} 100 / 1062=40.77 \%$ & 37.85 & 43.75 \\
\cline { 2 - 6 } & $41-60$ & 476 & $476 * 100 / 1062=44.82 \%$ & 41.85 & 47.82 \\
\cline { 2 - 6 } & $>60$ & 102 & $102 * 100 / 1062=9.61 \%$ & 7.98 & 11.53 \\
\hline Total & 1062 & $1062 * 100 / 1062=100 \%$ & \multicolumn{2}{|c|}{ Population parameters } \\
\hline
\end{tabular}

Table 3.2.1.1: Observed, expected and adjusted expected counts and percentages for distribution of active hepatitis $\mathbf{C}$ infected population by sex in District D.I.Khan, Pakistan

\begin{tabular}{|l|c|c|c|c|c|c|}
\hline $\begin{array}{l}\text { Column1- } \\
\text { Sex }\end{array}$ & $\begin{array}{c}\text { C2-Observed } \\
\text { counts }\end{array}$ & $\begin{array}{c}\text { C3-Expected } \\
\text { counts }\end{array}$ & $\begin{array}{c}\text { C4-Adjust- } \\
\text { ed expected } \\
\text { counts }\end{array}$ & $\begin{array}{c}\text { C5-Observed } \\
\% \text { ages }\end{array}$ & $\begin{array}{c}\text { C6-Expected } \\
\% \text { ages }\end{array}$ & $\begin{array}{c}\text { C7-Adjusted ex- } \\
\text { pected \% }\end{array}$ \\
\hline Men & 569 & 232 & $\begin{array}{c}232 * 1062 / 378 \\
=651.81\end{array}$ & $\begin{array}{c}569 * 100 / 1062 \\
=53.58 \%\end{array}$ & $\begin{array}{c}232 * 100 / 378 \\
=61.38 \%\end{array}$ & $\begin{array}{c}651.81 * 100 / 1062 \\
=61.38 \%\end{array}$ \\
\hline Women & 493 & 146 & $\begin{array}{c}146 * 1062 / 378 \\
=410.19\end{array}$ & $\begin{array}{c}493 * 100 / 1062 \\
=46.42 \%\end{array}$ & $\begin{array}{c}146 * 100 / 378 \\
=38.62 \%\end{array}$ & $\begin{array}{c}410.19 * 100 / 1062 \\
=38.62 \%\end{array}$ \\
\hline Total & 1062 & 378 & 1062 & $100 \%$ & $100 \%$ & $100 \%$ \\
\hline
\end{tabular}

Table 3.2.1.2: Observed vs. expected distribution of active hepatitis $C$ infected population by sex in District D.I.Khan, Pakistan

\begin{tabular}{|l|c|c|c|c|c|c|}
\hline Sex & Observed count $(\mathrm{O})$ & Expected count $(\mathrm{E})$ & $\mathrm{O}-\mathrm{E}$ & $(\mathrm{O}-\mathrm{E})^{2}$ & $X^{2}$ & $\mathrm{p}$-value \\
\cline { 1 - 6 } Men & 569 & 651.81 & -82.81 & 6857.5 & 10.52 & \multirow{2}{*}{$<.0001$} \\
\cline { 1 - 5 } Women & 493 & 410.19 & 82.81 & 6857.5 & 16.72 & \\
\hline Total & 1062 & 1062 & 00 & $\Sigma X^{2}$ & 27.24 & \multirow{2}{*}{ d.f. $=1$} \\
\hline
\end{tabular}


Table 3.2.2.1: Observed, expected and adjusted expected counts and percentages for distribution of active hepatitis $\mathbf{C}$ infected population by age groups in District D.I.Khan, Pakistan

\begin{tabular}{|c|c|c|c|c|c|c|}
\hline $\begin{array}{l}\text { Column 1- } \\
\text { Age groups }\end{array}$ & $\begin{array}{l}\text { C2-Obser- } \\
\text { ved counts }\end{array}$ & $\begin{array}{l}\text { C3-Expect- } \\
\text { ed counts }\end{array}$ & $\begin{array}{l}\text { C4-Adjusted ex- } \\
\text { pected counts }\end{array}$ & $\begin{array}{c}\text { C5-Observed } \\
\text { \%ages }\end{array}$ & $\begin{array}{c}\text { C6-Expected } \\
\text { \%ages }\end{array}$ & $\begin{array}{c}\text { C7-Adjusted ex } \\
\text { pected \%ages }\end{array}$ \\
\hline $\begin{array}{l}0-20 \\
\text { Years }\end{array}$ & 51 & 26 & $\begin{array}{c}26 * 1062 / 378 \\
=73.05\end{array}$ & $\begin{array}{c}51 * 100 / 1062 \\
=4.80 \%\end{array}$ & $\begin{array}{c}26 * 100 / 378 \\
=6.88 \%\end{array}$ & $\begin{array}{c}73.05 * 100 / 1062 \\
=6.88 \%\end{array}$ \\
\hline $\begin{array}{l}21-40 \\
\text { Years }\end{array}$ & 433 & 178 & $\begin{array}{c}178 * 1062 / 378 \\
=500.09\end{array}$ & $\begin{array}{c}433 * 100 / 1062 \\
=40.77 \%\end{array}$ & $\begin{array}{c}178 * 100 / 378 \\
=47.09 \%\end{array}$ & $\begin{array}{c}500.09 * 100 / 1062 \\
=47.09 \%\end{array}$ \\
\hline $\begin{array}{l}41-60 \\
\text { Years }\end{array}$ & 476 & 171 & $\begin{array}{c}171 * 1062 / 378 \\
=480.43\end{array}$ & $\begin{array}{c}476 * 100 / 1062 \\
=44.82 \%\end{array}$ & $\begin{array}{c}171 * 100 / 378 \\
=45.24 \%\end{array}$ & $\begin{array}{c}480.43 * 100 / 1062 \\
=45.24 \%\end{array}$ \\
\hline $\begin{array}{l}>60 \\
\text { Years }\end{array}$ & 102 & 3 & $\begin{array}{c}3^{*} 1062 / 378 \\
\quad=8.43\end{array}$ & $\begin{array}{c}102 * 100 / 1062 \\
=9.61 \%\end{array}$ & $\begin{array}{c}3 * 100 / 378 \\
=0.79 \%\end{array}$ & $\begin{array}{c}8.43 * 100 / 1062 \\
\quad=0.79 \%\end{array}$ \\
\hline Total & 1062 & 378 & 1062 & $100 \%$ & $100 \%$ & $100 \%$ \\
\hline
\end{tabular}

Table 3.2.2.2: Observed vs. expected distribution of active hepatitis $C$ infected population by age groups in District D.I.Khan, Pakistan $(n=1,062)$

\begin{tabular}{|c|c|c|c|c|c|c|}
\hline Age groups & Observed count $(\mathrm{O})$ & Expected count $(E)$ & O-E & (O-E)2 & $x^{2}$ & $\mathrm{p}$-value \\
\hline 0-20 Years & 51 & 73.05 & -22.05 & 486.20 & 6.66 & \multirow{4}{*}{$<.0001$} \\
\hline 21-40 Years & 433 & 500.09 & -67.09 & 4501.07 & 9.00 & \\
\hline 41-60 Years & 476 & 480.43 & -4.43 & 19.62 & 0.04 & \\
\hline$>60$ Years & 102 & 8.43 & 93.57 & 8755.34 & 1038.59 & \\
\hline Total & 1062 & 1062 & 00 & $\Sigma X^{2}$ & 1054.29 & d.f. $=3$ \\
\hline
\end{tabular}

are adjusted to our sample size (C4). C5, C6 \& C7 shows relevant percentages. (Table 3.2.2.1)

With $\mathrm{p}$-value $<.0001, \mathrm{H}_{02}$ was rejected, confirming that the observed counts are different from the expected counts. Simply, our observed prevalence in the four age groups was different than expected (adjusted) for the four age groups. (Table 3.2.2.2)

\section{DISCUSSION}

4.1 Distribution of active hepatitis $C$ infected population by sex $\left(H_{01}\right)$ : In our data $(n=1062)$ active hepatitis $\mathrm{C}$ infection was more common in men $53.58 \%(95 \% \mathrm{Cl} 50.57-56.56)$ than women $46.42 \%$ (95\% Cl 43.44-49.43). (Table 3.1.1)

Similar to our findings, higher frequency in men than women were proved by Jan, et al. ${ }^{11}(64.44 \%$ vs. $35.56 \%$ ), Ullah, et al. ${ }^{8}$ (61.38\% vs. $\left.38.62 \%\right)$, Khan, et al. ${ }^{9}$ from Takht Bhai, Mardan, Pakistan $(76.47 \%$ vs. $23.53 \%$ ), Khan, et al. ${ }^{10}$ from Batkhela, Malakand District, Pakistan $(56.52 \%$ vs. $43.48 \%)$ \& Suntur, et al. $^{3}$ from Adana, Turkey (69.51\% vs. $\left.30.49 \%\right)$.

Dissimilar to our results, lower frequency in men than women were highlighted by Kumar, et al. ${ }^{6}(43.09 \%$ vs. $56.91 \%)$, Ahsan, et al. ${ }^{7}$ (48.24\% vs. $51.76 \%$ ), Sharma, et al. ${ }^{5}$ from India (47.06\% vs. $\left.52.94 \%\right)$ and Soliman, et al. $^{4}$ from Luxor, Egypt (35.18\% vs. $\left.64.82 \%\right)$. No study demonstrating similar prevalence in men and women could be sorted out from literature.
Our observed prevalence of active hepatitis $C$ infected population in men $53.58 \%$ was lower than what we expected (adjusted) for men $61.38 \%$ \& our observed prevalence of active hepatitis $C$ infected population in women $46.42 \%$ was higher to what we expected (adjusted) for women $38.62 \%$ from the study by Ullah, et al. ${ }^{8}$ from Mardan, Pakistan. (Table 3.2.1.2)

4.2 Distribution of active hepatitis $C$ infected population by age groups $\left(\mathrm{H}_{02}\right)$ : In our data $(n=$ 1062) active hepatitis $C$ infection was most common $44.82 \%(95 \% \mathrm{Cl} 41.85-47.82)$ in age group $41-60$ years, followed by $40.77 \%$ (95\% Cl $37.85-43.75)$ in $21-40$ years, $9.61 \%(95 \% \mathrm{Cl} 7.98-11.53)$ in $>60$ years and $4.80 \%(95 \% \mathrm{Cl} 3.67-6.26)$ in $0-20$ years. (Table 3.1.1)

Ullah, et al. ${ }^{8}$ found that active hepatitis $\mathrm{C}$ infection was most common $47.09 \%$ in age group $21-40$ year, followed by $45.24 \%$ in $41-60$ years, $6.88 \%$ in $11-20$ years and $0.79 \%$ in $\geq 61$ years.

Ahsan, et al. ${ }^{7}$ found that seropositive HCV infection was most common $44.55 \%$ in age group $21-40$ years, followed by $42.33 \%$ in $41-60$ years, $7.02 \%$ in $0-20$ years and $6.10 \%$ in $\geq 61$ years.

Khan, et al. ${ }^{10}$ from Batkhela, Malakand District, Pakistan found that seropositive HCV infection was most common $31.71 \%$ in age group $41-60$ years, followed by $29.27 \%$ in $21-40$ years, $26.83 \%$ in $\geq 61$ years and $12.19 \%$ in $0-20$ years. 
Kumar, et al. ${ }^{6}$ found that active HCV infection was most common $52.85 \%$ in age group of $>41$ years, followed by $38.21 \%$ in $21-40$ years and $8.94 \%$ in 10-20 years.

Jan, et al. ${ }^{11}$ found that seropositive HCV infection was most common $33.33 \%$ in age group $16-30$ years, followed by $31.11 \%$ in $31-45$ years, $24.45 \%$ in $46-60$ years, $6.67 \%$ in $1-15$ years and $4.44 \%$ in $61-75$ years. Our observed prevalence of active hepatitis $\mathrm{C}$ infected population in the four age groups was not similar to what we expected (adjusted) for the four age groups from the study by Ullah, et al. ${ }^{8}$ from Mardan, Pakistan. (Table 3.2.2.2)

4.3 Marwat Logical Trajectory of Research Process: We designed our project according to the innovated model of "Marwat Logical Trajectory of Research Process". ${ }^{17-21}$

\section{CONCLUSIONS}

In our study, active hepatitis $C$ infection was more common in men than women and most common in age group 41-60 years, followed by $21-40,>60$ \& 0-20 years. Our observed prevalence of active hepatitis $C$ infection in men was lower than expected \& in women it was higher than expected. Our observed prevalence of active hepatitis $\mathrm{C}$ infection in the four age groups was not similar to expected.

Acknowledgement: Dr. Muhammad Marwat from Gomal Medical College, D.I.Khan is highly acknowledged to grant us permission to use his "Marwat Logical Trajectory of Research Process" for this project and for his help in data analysis and manuscript organization.

\section{REFERENCES}

1. Key data at a glance. In: Global progress report on HIV, viral hepatitis and sexually transmitted infections, 2021. Accountability for the global health sector strategies 2016-2021: actions for impact [accessed 2021 April 29]. Geneva: World Health Organization; 2021. Available at: http:// apps.who.int/iris/

2. Global Hepatitis Report 2017 [accessed 2021 April 29]. Geneva: World Health Organization; 2017. Available at: http://apps.who.int/iris/

3. Suntur BM, Kaya H, Eker HBŞ, Kara B, Bozok T, Unal N. A cross-sectional study of real life data of HCV from Turkey south region. J Infect Dev Ctries 2020 Apr 30; 14(4):380-6. https://doi.org/10.3855/ jidc. 11983

4. Soliman G, Elzalabany MS, Hassanein T, Miller FD. Mass screening for hepatitis $B$ and $C$ in southern upper Egypt. BMC Public Health 2019 Oct 22; 19(1):1326. https://doi.org/10.1186/ s12889-019-7640-1

5. Sharma H, Zaidi VM, Mahajan D, Kumari S. Hepatitis $\mathrm{C}$ seroprevalence among a tertiary hospital based general population in northern India. Eur J Mol Clin Med 2020 Dec 25; 7(7):4088-94.
6. Kumar T, Ahmad N, Hayat MK, Gao BX, Faisal $\mathrm{S}$, llahi $\mathrm{N}$, et al. Prevalence and genotypic distribution of hepatitis $C$ Virus in Peshawar, KPK, Pakistan. HAYATI J Biosci 2017 Jan 1; 24(1):22-5. https://doi.org/10.1016/j.hjb.2017.04.002

7. Ahsan J, Zafar U, Ayub R, Malik AA, Zaman A, Ahmad W, et al. The frequency of Hepatitis B \& $C$ in patients presenting to Khyber College of Dentistry Peshawar. J Khyber Coll Dent 2018 Mar; 8(1):54-8.

8. Ullah N, Kakakhel MA, Bai Y, Xi L, Khan I, Kalra $\mathrm{BS}$, et al. Prevalence of active HCV infection and genotypic distribution among the general population of district Mardan, Pakistan. Braz J Biol 2021; 83. https://doi.org/10.1590/1519-6984.244977

9. Khan M, Jalil F, Din M, Ali S, Ahmad A. Seroprevalence and risk factors of hepatitis $\mathrm{C}$ virus (HCV) in tehsil Takht Bhai district Mardan, KPK, Pakistan. Int J Biosci 2018 May 30;12(5):249-54. https://doi. org/10.12692/ijb/12.5.249-254

10. Khan M, Khan S, Haider S, Jalil F, Jamal M, Ah$\operatorname{mad} A$. Prevalence and risk factors of hepatitis $C$ virus (HCV) in Tehsil Batkhela, District Malakand, KPK, Pakistan. Int J Contemp Res Rev 2018 Jun 10; 9(06):20251-6. https://doi.org/10.15520/ ijcrr/2018/9/06/525

11. Jan N, Awan ZU, Awan MU. Hepatitis C virus $(\mathrm{HCV})$ infection in general population of District Bannu, Khyber Pakhtunkhwa, Pakistan. Pure Applied Biol 2020 Aug 12; 9(3):1679-89. https:// doi.org/10.19045/bspab.2020.90178

12. Raosoft $\circledast$ sample size calculator [internet]. Seattle, WA, USA: Raosoft Inc.; 2004. [Accessed 2021 April 30]. Available at: http://www. raosoft. com/samplesize.html

13. Statistics Kingdom. Proportion confidence interval calculator [internet]. Statistics Kingdom; Melbourne, Australia 2007. [Accessed 2021 April 30]. Available at: http://www.statskingdom. com/41_proportion_confidence_interval.html

14. Zar JH. Biostatistical Analysis. 5th ed. New York: Prentice-Hall, Inc.

15. Daniel WW. Biostatistics: A Foundation for Analysis in the Health Sciences. 7th ed. Singapore: John Wily; 2005

16. Social Science Statistics. Statistical Tests Calculators [Internet]. [Accessed 2021 May 02]. Available at: https://www.socscistatistics.com/ tests/goodnessoffit/default2.aspx

17. Ghori MR, Khan H, Marwat M. Distribution of non-malignant hematological disorders by sex, age groups and type of disease based on bone marrow aspiration in population of Khyber Pakhtunkhwa, Pakistan. Gomal J Med Sci 2019 Apr-Jun; 17 (2): 29-36. https://doi.org/10.46903/gjms/17.02.1926

18. Ain N, Khan S, Marwat M, Khan N, Ahmad I, Ramzan $\mathrm{F}$, et al. Frequency, distribution and determinants of hypertension in adult stroke population of D.I.Khan Division, Pakistan. Gomal J Med Sci 2019 Jul-Sep; 17 (3):81-9. https://doi. org/10.46903/gjms/17.03.2076 
19. Marwat M, Ahmad I, Ashiq F, AliS, ZamirS, Rehman MU, et al. Frequency, distribution and determinants of diabetes mellitus in adult acute coronary syndrome population of D.I.Khan Division, Pakistan. Gomal J Med Sci 2019 OctDec;17 (4):131-43. https://doi.org/10.46903/ gjms/17.04.2106

20. Naqvi SWA, Saeed S, Rafique A, Saeed MH, Khan $\mathrm{N}$, Khan A, et al. Prevalence and distribution of malaria by sex, age groups and species in year
2019 in suspected malarial population of district D.I.Khan, Pakistan. Gomal J Med Sci 2020 OctDec; 18(4):164-73.

21. Rashid M, Rehman $Y$, Usman M, Younas M, Bilal M, Jamil M, et al. Distribution of cutaneous leishmaniasis by sex, age groups and residence in year 2020 in cutaneous leishmaniasis population of District D.I.Khan, Pakistan. Gomal J Med Sci 2021 Jan-Mar; 19(1):28-34. https://doi. org/10.46903/gjms/19.01.964
CONFLICT OF INTEREST

Authors declare no conflict of interest. GRANT SUPPORT AND FINANCIAL DISCLOSURE None declared.

\section{AUTHORS' CONTRIBUTION}

The following authors have made substantial contributions to the manuscript as under:

Conception or Design:

Acquisition, Analysis or Interpretation of Data:

Manuscript Writing \& Approval:

All the authors agree to be accountable for all aspects of the work in ensuring that questions related to the accuracy or integrity of any part of the work are appropriately investigated and resolved. 